\title{
Elevation gradient of soil bacterial communities in bamboo plantations
}

\author{
Yu-Te Lin and Chih-Yu Chiu* ${ }^{*}$
}

\begin{abstract}
Background: Elevation trends of macro organisms have long been well studied. However, whether microbes also exhibit such patterns of elevation change is unknown. Here, we investigated the changes in bamboo forest soil bacterial communities along six elevation gradients, from 600 to $1800 \mathrm{~m}$ a.s.l. in Mt. Da-an, a subtropical montane area in Nantou county at central Taiwan.

Results: Data from $16 \mathrm{~S}$ rRNA gene clone libraries revealed that more than $70 \%$ of the six communities contained Acidobacteria and Proteobacteria, although the relative abundance differed. Nonmetric multidimensional scaling analysis of the distribution of operational taxonomic units showed differences in bamboo soil bacterial communities across gradients. The bacterial communities at 1000 and $1200 \mathrm{~m}$ showed greater diversity than the communities at both lower (600 and $800 \mathrm{~m}$ ) and higher (1400 and $1800 \mathrm{~m}$ ) elevations. In contrast to the bacterial community trend, soil $\mathrm{C}$ and $\mathrm{N}$ and microbial biomass properties increased linearly with elevation.

Conclusion: The bamboo soil bacterial community could interact with multiple factors such as soil organic matter content and temperature, for differences in composition and diversity with change in elevation.
\end{abstract}

Keywords: Bamboo, Soil, 165 rRNA genes, Elevation, Bacterial diversity

\section{Background}

Understanding the responses of soil communities across elevation gradients has long been a fascinating topic for ecologists. The composition of macro organisms along elevation gradients have been well studied (Herzog et al. 2005; Rahbek 2005; Kreft and Jetz 2007; McCain 2009). However, the distribution of microorganisms might not follow the same ecological rules as for macro organisms. For instance, the number of total bacteria, methanotrophic bacteria and ammonia-oxidizing archaea was negatively correlated with increasing elevation (Ma et al. 2004; Giri et al. 2007; Zhang et al. 2009), but the content of Gram-negative bacteria increases with increasing elevation in the Austrian central Alps (Margesin et al. 2009). Also, bacterial diversity decreased with elevation in the mountains of the southwestern United States (Bryant et al. 2008). However, in eastern Peru, the

\footnotetext{
*Correspondence: bochiu@sinica.edu.tw

Biodiversity Research Center, Academia Sinica, Nankang, Taipei 11529, Taiwan
}

\section{Springer}

community diversity did not show a significant elevation gradient (Fierer et al. 2011). In South Korea, higher diversity occurs at high and low elevations, with minimum richness at middle elevations (Singh et al. 2014). Our understanding of major determinants of the distribution of bacteria is still largely limited. Considering the essential roles of microorganisms in many biogeochemical cycles in ecosystems, more studies on the bacterial trends among different mountain ecosystems are needed.

In East Asia, bamboo is one of the most important forest resources and can be used as construction or furniture material. Young bamboo shoots are also in high demand as a healthy food. Regular management, such as removal of understory vegetation as well as tillage and fertilizer application, is often used to maintain and increase bamboo production.

In the present study, we collected soil samples from moso bamboo plantations along six elevations, from 600 to $1800 \mathrm{~m}$ a.s.l., in central Taiwan. This transect provides an opportunity to study elevation distribution without the effects of different vegetation. Previously, we 
found the high-elevation bamboo plantations (1200 and $1400 \mathrm{~m}$ ) significantly differed from low elevation plantations $(600,800$, and $1000 \mathrm{~m}$ ), with higher soil $\mathrm{C}$ and $\mathrm{N}$ contents, higher concentrations of soil soluble organic $\mathrm{C}$ and $\mathrm{N}$, and a greater amount of soil microbial biomass $C$ and $N$ (Huang et al. 2014). However, the bacterial community trend along elevation gradients is still unknown. Using $16 \mathrm{~S}$ rRNA gene clone library analysis, we attempted to elucidate the responses of the structure and diversity of the bamboo soil bacterial community to elevation gradients.

\section{Methods}

\section{Site description and soil sampling}

The study site was located at Mt. Da-an, a subtropical montane area in Nantou County, central Taiwan $\left(23^{\circ} 42^{\prime} \mathrm{N}, 120^{\circ} 41^{\prime} \mathrm{E}\right)$. Soil samples were collected from moso bamboo (Phyllostachys edulis) plantations along a county road with an increasing altitudinal gradient, $600,800,1000,1200,1400$ and $1800 \mathrm{~m}$ a.s.l. The six sampling gradients are all dominated by moso bamboo with few understory plants. The bamboo plantations in this area were established simultaneously around the 1960s. Both the culm density and culm age of the selected moso bamboo plantations were similar between elevations. However, aboveground bamboo biomass increased with elevation (Chen et al. 2014). The soils are well drained and characterized as Entisols. The parent material is sandstone and shale. The soils are loam with pH 3.9-4.4. Other properties of soils are reported in Table 1.

At each elevation, three $25 \times 25 \mathrm{~m}$ plots were established along transect lines in January 2012. The soil samples were collected in winter to avoid differences caused by seasonal changes. Within each plot, three subsamples were collected by use of a soil auger $8 \mathrm{~cm}$ in diameter and $10 \mathrm{~cm}$ deep and were combined. Visible detritus materials, such as roots and litter, were manually removed prior to passing soil through a 2-mm sieve. Soils were then stored at $-20{ }^{\circ} \mathrm{C}$, and extraction of soil community DNA was performed within 2 weeks.

Table 1 Soil chemical and physical properties of study sites

\begin{tabular}{lcccr}
\hline Elevation $(\mathbf{m})$ & $\mathbf{p H}$ & $\begin{array}{l}\text { Organic } \mathbf{C} \\
\left(\mathbf{g ~ k g}^{-\mathbf{1}} \mathbf{)}\right.\end{array}$ & $\begin{array}{l}\text { Total } \mathbf{N} \\
\left(\mathbf{g} \mathbf{~ k g}^{-\mathbf{1}} \mathbf{)}\right.\end{array}$ & $\mathbf{C / N}$ \\
\hline 600 & 4.0 & 25.3 & 2.4 & 10.5 \\
800 & 3.9 & 35.8 & 3.6 & 9.9 \\
1000 & 3.8 & 39.3 & 3.8 & 10.3 \\
1200 & 3.7 & 64.9 & 6.1 & 10.6 \\
1400 & 3.4 & 63.8 & 5.2 & 12.3 \\
1800 & 4.4 & 151.3 & 10.2 & 14.8 \\
\hline
\end{tabular}

\section{S rRNA gene clone library construction and sequencing}

The 16S rRNA gene clone libraries were constructed as described (Lin et al. 2010). In brief, soil community DNA was extracted by using the PowerSoil ${ }^{\circledR}$ Soil DNA Isolation kit (MoBio Industries, Carlsbad, CA, USA) following the manufacturer's instructions. The bacterial 16S rRNA genes were amplified by PCR with the primer set $27 \mathrm{~F}$ and 1492R (Lane 1991). After 15 cycles, the PCR products were cloned by using the TOPO TA cloning kit (Invitrogen, Carlsbad, CA, USA) and the pCR2.1 vector. White colonies on selective Luria-Bertani (LB) agar plates were picked into 96-well blocks containing $1 \mathrm{ml} \mathrm{LB}$ broth plus kanamycin $\left(50 \mu \mathrm{g} \mathrm{ml}^{-1}\right)$ and grown overnight. Sterile glycerol was added to a final concentration of $10 \%$, and an aliquot was transferred to a 96-well sequencing block. Both the sequencing and the original culture blocks were stored at $-80^{\circ} \mathrm{C}$.

\section{DNA sequencing and sequence analyses}

Bacterial clones were partially sequenced with the primer 27F. Sequence analysis involved an ABI PRISM Big Dye Terminator cycle sequencing ready reaction kit (Applied Biosystems, Foster City, CA, USA) and an ABI 3730 Genetic Analyzer (Applied Biosystems) following the manufacturer's instructions. Sequences were analyzed with the Mallard and Pintail programs to test for chimeras (Ashelford et al. 2005, 2006). The entire clone sequences obtained in the study have been deposited to GenBank (accession numbers KJ407398-KJ408214 and KM108145-KM108301).

Taxonomic assignment of sequences from the clone library was made using the naïve Bayesian rRNA classifier (Wang et al. 2007) in the Ribosomal Database Project (RDP) (http://rdp.cme.msu.edu/index.jsp). Diversity estimates, including Shannon diversity index, Chao1 estimator and rarefaction analysis, were calculated for operational taxonomic units (OTUs) with $97 \% 16 \mathrm{~S}$ rRNA gene sequence similarity by using the program DOTUR (Schloss and Handelsman 2005). PRIMER V6 (PRIMERE, Lutton, Ivybridge, UK) was used for non-metric multidimensional scaling (NMDS) generated with Bray-Curtis similarity of sequence data. Mantel tests as implemented in PRIMER v6 were also assessed to analyze the relationships between phylogenetic distances of bacterial communities and soil properties.

\section{Results}

Phylogenetic groups of bacterial community

About 50-60 clones of $16 \mathrm{~S}$ rRNA genes were derived from each of the three replicate samples. The sequences from replicates of each elevation were then combined for further analysis. A total of 151-182 bacterial sequences 
were obtained from each of six elevations. Phylogenetic analysis revealed that the communities were composed of 11 bacterial groups. The Acidobacteria (comprising 46-64 \% of all clones from each elevation) and Proteobacteria-affiliated clones (24-37\%) were the two most abundant phyla (Fig. 1). The relative abundance of Actinobacteria and Firmicutes in the community at 1000 and $600 \mathrm{~m}$, respectively, was higher than that in other communities. Other phyla including Bacteroidetes, Chloroflexi, Cyanobacteria, Gemmatimonadetes, Planctomycetes and Verrucomicrobia, were all less abundant and accounted for less than $5 \%$ of the clones (Fig. 1).

Within the Acidobacteria, GP1, 2 and 3 were all abundant groups in the six communities, but the relative

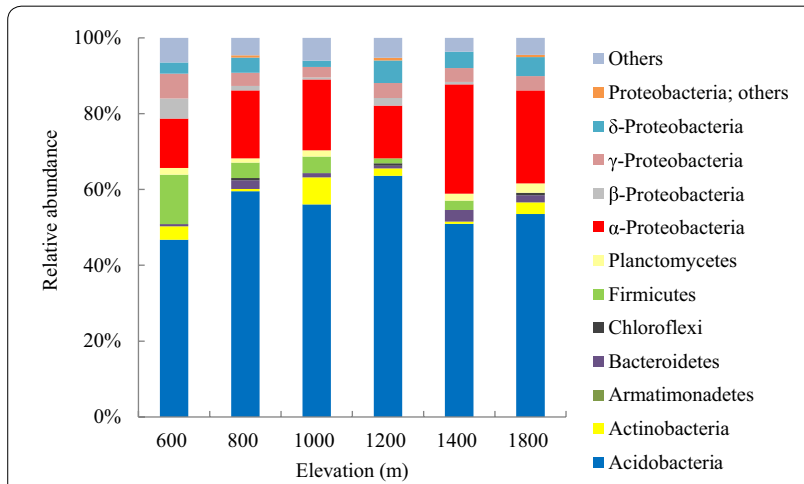

Fig. 1 Relative abundance of phylogenetic groups in 16S rRNA gene libraries along elevational gradients abundance of GP2 at $1400 \mathrm{~m}$, and GP3 at 600, 800 and $1800 \mathrm{~m}$ was less than $10 \%$ (Table 2). The relative abundance of Bacillales was higher at $600 \mathrm{~m}$ than that in other communities (Table 2). Within the $\alpha$-Proteobacteria, Rhizobiales was more abundant in the communities at 1400 and $1800 \mathrm{~m}$. The relative abundance of Rhodospirillales was higher at $1000 \mathrm{~m}$ than that in the other communities (Table 2).

\section{Bacterial diversity}

The community diversity indices were calculated based on the OTUs with $97 \%$ sequence similarity. Although we observed no clear trends in diversity indices (Table 3), analyses of rarefaction curves suggested that communities at 1000 and $1200 \mathrm{~m}$ were the most diverse, and the communities at the lowest elevation of $600 \mathrm{~m}$ and the highest elevation of $1800 \mathrm{~m}$ were the least diverse (Fig. 2).

\section{Bacterial community comparison}

On NMDS analysis of the library, the composition of bamboo soil bacterial community differed across elevation gradients (Fig. 3). The communities in 600 and $1000-\mathrm{m}$ soils were more separated from other communities. Examining the distribution of OTUs also revealed differences in composition. The distribution of the 10 most abundant OTUs, affiliated with Acidobacteria and $\alpha$-Proteobacteria, differed by elevation (Table 4). OTU 8 could be found in all six communities, with OTU 29 not found in soils at 600 and $1800 \mathrm{~m}$. Likewise, OTUs

Table 2 The 10 most abundant phylogenetic groups detected in bamboo soil communities along elevation gradients

\begin{tabular}{|c|c|c|c|c|c|c|}
\hline \multirow[t]{2}{*}{ Phylogenetic group } & \multicolumn{6}{|c|}{ Percentage of clones } \\
\hline & $600 \mathrm{~m}$ & $800 \mathrm{~m}$ & $1000 \mathrm{~m}$ & $1200 \mathrm{~m}$ & $1400 \mathrm{~m}$ & $1800 \mathrm{~m}$ \\
\hline \multicolumn{7}{|l|}{ Acidobacteria } \\
\hline $\mathrm{GP} 1^{\mathrm{a}}$ & 25.3 & 37.0 & 19.8 & 29.8 & 17.9 & 18.9 \\
\hline GP2 & 10.2 & 8.7 & 17.6 & 17.2 & 9.0 & 23.3 \\
\hline GP3 & 6.6 & 7.5 & 15.9 & 12.6 & 21.4 & 3.8 \\
\hline GP5 & 3.6 & 2.9 & 1.1 & 2.0 & 2.1 & 1.9 \\
\hline \multicolumn{7}{|l|}{ Bacteroidetes } \\
\hline Sphingobacteriales & 0.6 & 2.3 & 1.1 & 0.7 & 3.4 & 1.9 \\
\hline \multicolumn{7}{|l|}{ Firmicutes } \\
\hline Bacillales & 10.8 & 3.5 & 0.5 & 1.3 & 0.7 & 0.0 \\
\hline \multicolumn{7}{|l|}{ Planctomycetes } \\
\hline Planctomycetales & 3.0 & 0.6 & 1.6 & 0.0 & 3.4 & 2.5 \\
\hline \multicolumn{7}{|l|}{ a-Proteobacteria } \\
\hline Rhizobiales & 5.4 & 12.1 & 9.3 & 10.6 & 20.0 & 20.1 \\
\hline Rhodospirillales & 2.4 & 4.6 & 8.2 & 3.3 & 4.8 & 3.1 \\
\hline \multicolumn{7}{|l|}{ y-Proteobacteria } \\
\hline Xanthomonadales & 4.8 & 2.3 & 2.2 & 1.3 & 3.4 & 3.8 \\
\hline
\end{tabular}

a GP, group 
Table 3 Diversity of soil bacterial communities detected in 16S rRNA gene clone libraries ${ }^{a}$

\begin{tabular}{|c|c|c|c|c|c|c|}
\hline \multirow[t]{2}{*}{ Measure of diversity } & \multicolumn{6}{|c|}{ Elevation $(\mathrm{m})$} \\
\hline & 600 & 800 & 1000 & 1200 & 1400 & 1800 \\
\hline No. of sequences & 169 & 173 & 182 & 151 & 163 & 159 \\
\hline No. of OTUs & 89 & 73 & 94 & 80 & 79 & 59 \\
\hline Shannon ${ }^{b}$ & 4.29 & 3.93 & 4.27 & 4.07 & 4.08 & 3.82 \\
\hline Chao 1 & 132 & 112 & 151 & 134 & 124 & 80 \\
\hline 95 \% Chao 1 & $110-179$ & $90-162$ & $123-209$ & 106-192 & $100-176$ & $67-117$ \\
\hline
\end{tabular}

a Calculations were based on operational taxonomic units (OTUs) with $97 \% 16 \mathrm{~S}$ rRNA gene sequence similarity

b Shannon diversity index $(H)$

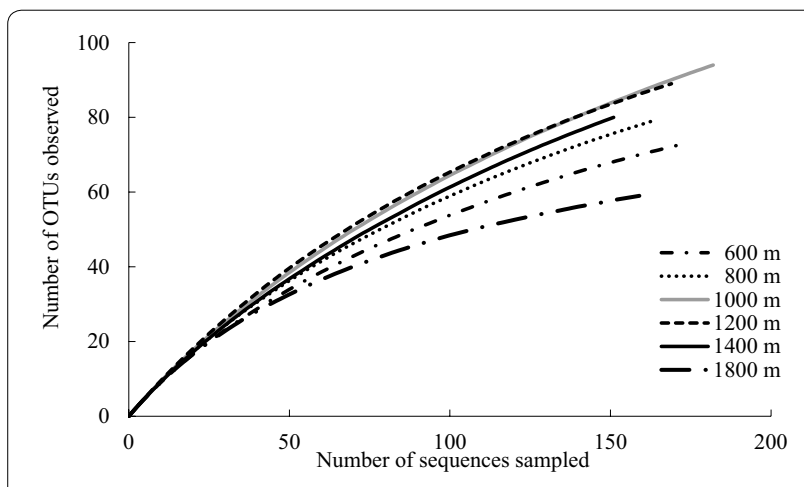

Fig. 2 Rarefaction curve analysis for the bamboo soil libraries with operational taxonomic units (OTUs) with $97 \%$ nucleotide sequence similarity

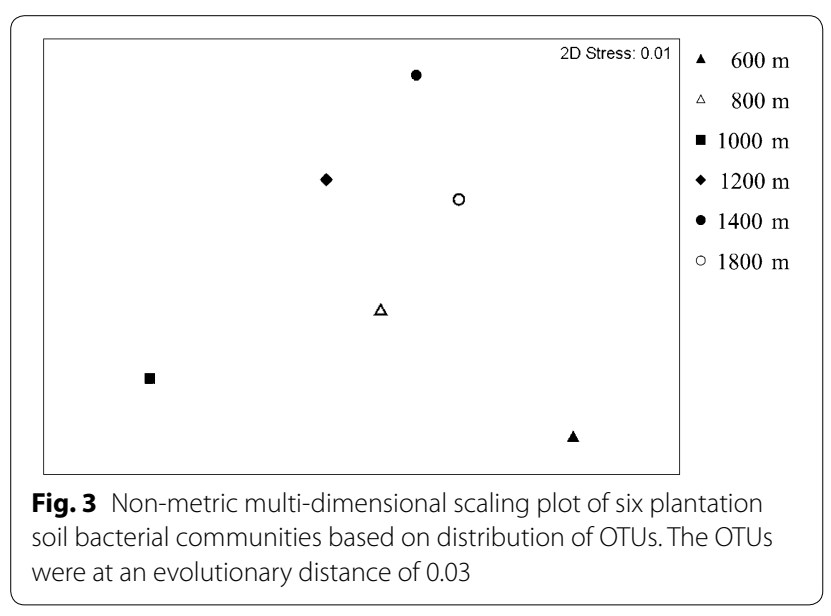

23 and 50 were present only in soils lower than $1000 \mathrm{~m}$. OTU distribution was not significantly correlated associated with environmental parameters, including elevation, organic $\mathrm{C}$, total $\mathrm{N}, \mathrm{C} / \mathrm{N}$ ratio and soil $\mathrm{pH}(P>0.05$; data not shown).

\section{Discussion}

In the present study, along six elevation gradients from 600 to $1800 \mathrm{~m}$ a.s.l. in bamboo forests, the soil bacterial communities at 1000 and $1200 \mathrm{~m}$ a.s.l. showed higher levels of diversity than those at both lower and higher elevations. The diversity differed from the monotonic and unimodal patterns observed for macro organisms (Rahbek 2005; McCain 2009). This result is similar to the changes in bacterial diversity with elevation on Mount Fuji (Singh et al. 2012), suggesting that the pattern of bamboo soil bacterial diversity along elevation gradients is different from that of plants and animals. With phospholipid fatty acid and denaturing gradient gel electrophoresis analysis, the microbial community the low and high elevations (Chang et al. 2016). In a comprehensive analysis of soil bacterial communities across six elevations representing six vegetation types from forest to alpine tundra in Mt. Changbai, China, $\mathrm{pH}$ was the best predictor of community composition, and vegetation could have indirectly affected the communities by altering soil $\mathrm{C}$ and $\mathrm{N}$ status across elevation gradients (Shen et al. 2013). In the present study, the range of soil $\mathrm{pH}$ was narrow (3.4-4.4), and $\mathrm{pH}$ was not significantly correlated with bacterial community structure. Because small $\mathrm{pH}$ changes could cause differences in bacterial communities within short and long distances (Yergeau et al. 2010; Sagova-Mareckova et al. 2011), the effects of $\mathrm{pH}$ on the bamboo soil community in this region still need to be further investigated.

Disturbance can be a major factor affecting the bamboo soil bacterial diversity. In recent years, the major production area for timber and bamboo shoots has changed from 600 and $800 \mathrm{~m}$ to 1000 and $1200 \mathrm{~m}$ in this region. However, the plantations we studied possessed comparable culm density and ages, which indicates similar bamboo productivity and levels of disturbance. Because of the different owners, the bamboo plantations might have been subjected to different fertilizer application and stem harvest, and determining the exact influence of human 
Table 4 Relative abundance and phylogenetic affiliation of the ten most abundant OTUs ${ }^{a}$

\begin{tabular}{|c|c|c|c|c|c|c|c|c|}
\hline \multirow[t]{2}{*}{ ОтU } & \multirow[t]{2}{*}{ No. of sequences } & \multirow[t]{2}{*}{ Affiliation } & \multicolumn{6}{|c|}{ Elevation (m) } \\
\hline & & & 600 & 800 & 1000 & 1200 & 1400 & 1800 \\
\hline 8 & 50 & Rhodoplanes & 8 & 7 & 10 & 8 & 8 & 9 \\
\hline 95 & 28 & Acidobacteria & 0 & 7 & 9 & 9 & 3 & 0 \\
\hline 1 & 25 & Acidobacteria & 6 & 7 & 2 & 3 & 5 & 2 \\
\hline 49 & 20 & Bradyrhizobium & 1 & 7 & 1 & 1 & 10 & 0 \\
\hline 53 & 15 & Acidobacteria & 3 & 4 & 3 & 5 & 0 & 0 \\
\hline 10 & 14 & Acidobacteria & 2 & 0 & 1 & 1 & 5 & 5 \\
\hline 35 & 14 & Acidobacteria & 5 & 4 & 1 & 2 & 1 & 1 \\
\hline 23 & 11 & Rhodospirillaceae & 1 & 7 & 3 & 0 & 0 & 0 \\
\hline 50 & 11 & Acidobacteria & 4 & 6 & 1 & 0 & 0 & 0 \\
\hline 142 & 11 & Acidobacteria & 0 & 1 & 2 & 2 & 2 & 4 \\
\hline
\end{tabular}

a OTUs with $97 \% 16 \mathrm{~S}$ rRNA gene sequence similarity

activity is difficult. One study showed that the effects of disturbance could affect microbial communities across time (Keiser et al. 2011), suggesting the need for further elucidation in these communities.

The Acidobacteria were the most abundant group. They also predominate in other ecosystems, including agricultural systems and subtropical and tropical forests (Jangid et al. 2011; Araujo et al. 2012; Meng et al. 2013). Acidobacteria are generally considered as oligotrophs (Nemergut et al. 2010) and versatile heterotrophs, exhibiting slow metabolic rates under low-nutrient conditions (Ward et al. 2009). Bamboo could release a large number of allelopathic compounds. The heterotrophic ability to survive with allelopathic compounds could be further explored.

Proteobacteria were also abundant in these communities, with $\alpha$-Proteobacteria the most abundant across different elevations. Within $\alpha$-Proteobacteria, many sequences were related to the Rhizobiales and Rhodospirillales, indicating the potential role for $\mathrm{N}_{2}$ fixation, organic matter decomposition and plant growth promotion in the soils (Zhang and Xu 2008; Yarwood et al. 2009). Higher soil $\mathrm{C} / \mathrm{N}$ ratio in higher elevations may indicate lower amounts of available nitrogen and requirement for $\mathrm{N}_{2}$-fixing bacteria in the community. The relatively high abundance of Rhizobiales-affiliated OTUs at 1400 and $1800 \mathrm{~m}$ was associated with high soil $\mathrm{C} / \mathrm{N}$ ratio, which is an important factor to predict community structure (Chu et al. 2010).

The relative abundance of Bacteroidetes was higher at $1400 \mathrm{~m}$ than that at other elevations. Known as copiotrophic bacteria, Bacteroidetes species tend to be found in nutrient-rich environments (Fierer et al. 2007). High elevation with high amounts of organic $\mathrm{C}$ and lower decomposition rates could provide a favorable condition for the growth of Bacteroidetes. Our previous study also revealed a higher abundance of Bacteroidetes in a cedar forest than adjacent bamboo forest soils (Lin et al. 2013). These results suggest that the Bacteroidetes, as well as the phyla Acidobacteria and Proteobacteria, could play an important role in the soil bacterial community.

\section{Conclusion}

In conclusion, our study revealed that bacterial diversity of bamboo soil communities were lower at both lower and higher elevations in this mountain area of central Taiwan, with greater diversity at 1000 and $1200 \mathrm{~m}$. As well, the community structure differed by elevation. Considering the low sequence number in the clone library, further studies with more sequences and using next generation sequencing technique (e.g., pyrosequencing) are needed to address the responses of the bamboo soil community along elevation gradients.

\section{Competing interests}

The authors declare that they have no competing interests.

Received: 5 January 2016 Accepted: 23 February 2016

Published online: 29 February 2016

\section{References}

Araujo J, de Castro A, Costa MMC, Togawa RC, Pappas GJ Jr, Quirino BF, Bustamante MMC, Williamson L, Handelsman J, Krüger RH (2012) Characterization of soil bacterial assemblies in Brazilian savanna-like vegetation reveals Acidobacteria dominance. Microb Ecol 64:760-770

Ashelford KE, Chuzhanova NA, Fry JC, Jones AJ, Weightman AJ (2005) At least 1 in 20165 rRNA sequence records currently held in public repositories is estimated to contain substantial anomalies. Appl Environ Microbiol 71:7724-7736

Ashelford KE, Chuzhanova NA, Fry JC, Jones AJ, Weightman AJ (2006) New screening software shows that most recent large 16S rRNA gene clone libraries contain chimeras. Appl Environ Microbiol 72:5734-5741 
Bryant JA, Lamanna C, Morlon H, Kerkhoff AJ, Enquist BJ, Green JL (2008) Microbes on mountainsides: contrasting elevational patterns of bacterial and plant diversity. Proc Natl Acad Sci USA 105:11505-11511

Chang EH, Chen TH, Tian G, Chiu CY (2016) The effect of altitudinal gradient on soil microbial community activity and structure in moso bamboo plantations. Appl Soil Ecol 98:213-220

Chen TH, Chiu CY, Xie ZY, Wang S (2014) Growth characteristics of moso bamboo (Phyllostachys edulis) plantations at various altitudes in Da-an area, Nantou County. Quart J Chin For 47:181-192 (in Chinese)

Chu H, Fierer N, Lauber CL, Caporaso JG, Knight R, Grogan P (2010) Soil bacterial diversity in the Arctic is not fundamentally different from that found in other biomes. Environ Microbiol 12:2998-3006

Fierer N, Bradford MA, Jackson RB (2007) Toward an ecological classification of soil bacteria. Ecology 88:1354-1364

Fierer N, McCain CM, Meir P, Zimmermann M, Rapp JM, Silman MR, Knight R (2011) Microbes do not follow the elevational diversity patterns of plants and animals. Ecology 92:797-804

Giri DD, Shukla PN, Kashyap S, Singh P, Kashyap AK, Pandey KD (2007) Variation in methanotrophic bacterial population along an altitude gradient at two slopes in tropical dry deciduous forest. Soil Biol Biochem 39:2424-2426

Herzog SK, Kessler M, Bach K (2005) The elevational gradient in Andean bird species richness at the local scale: a foothill peak and a high-elevation plateau. Ecography 28:209-222

Huang CY, Jien SH, Chen TH, Tian G, Chiu CY (2014) Soluble organic C and N and its relationships with soil organic $\mathrm{C}$ and $\mathrm{N}$ and microbial characteristics in moso bamboo (Phyllostachys edulis) plantations along an elevation gradient in central Taiwan. J Soils Sediments 14:1061-1070

Jangid K, Williams MA, Franzluebbers AJ, Schmidt TM, Coleman DC, Whitman WB (2011) Land-use history has a stronger impact on soil microbial community composition than aboveground vegetation and soil properties. Soil Biol Biochem 43:2184-2193

Keiser AD, Strickland MS, Fierer N, Bradford MA (2011) The effect of resource history on the functioning of soil microbial communities is maintained across time. Biogeosciences 8:1477-1486

Kreft H, Jetz W (2007) Global patterns and determinants of vascular plant diversity. Proc Natl Acad Sci USA 104:5925-5930

Lane DJ (1991) 16S/23S rRNA sequencing. In: Stackebrandt E, Goodfellow M (eds) Nucleic acid techniques in bacterial systematics. Wiley, New York, pp 115-175

Lin YT, Huang YJ, Tang SL, Whitman WB, Coleman DC, Chiu CY (2010) Bacterial community diversity in undisturbed perhumid montane forest soils in Taiwan. Microb Ecol 59:369-378

Lin YT, Tang SL, Pai CW, Whitman WB, Coleman DC, Chiu CY (2013) Changes in the soil bacterial communities in a cedar plantation invaded by moso bamboo. Microb Ecol 67:421-429

Ma X, Chen T, Zhang G, Wang R (2004) Microbial community structure along an altitude gradient in three different localities. Folia Microbio 49:105-111

Margesin R, Jud M, Tscherko D, Schinner F (2009) Microbial communities and activities in alpine and subalpine soils. FEMS Microbiol Ecol 67:208-218

McCain CM (2009) Vertebrate range sizes indicate that mountains may be 'higher' in the tropics. Ecol Lett 12:550-560
Meng H, Li K, Nie M, Wan JR, Quan ZX, Fang CM, Chen JK, Gu JD, Li B (2013) Responses of bacterial and fungal communities to an elevation gradient in a subtropical montane forest of China. Appl Microbiol Biotechnol 97:2219-2230

Nemergut DR, Cleveland CC, Wieder WR, Washenberger CL, Townsend AR (2010) Plot-scale manipulations of organic matter inputs to soils correlate with shifts in microbial community composition in a lowland tropical rain forest. Soil Biol Biochem 42:2153-2160

Rahbek C (2005) The role of spatial scale and the perception of large-scale species-richness patterns. Ecol Lett 8:224-239

Sagova-Mareckova M, Omelka, M. Cermak L, Kamenik Z, Olsovska J, Hackl, E, Kopecky J, Hadacek, F (2011) Microbial communities show parallels at sites with distinct litter and soil characteristics. Appl Environ Microbiol 77:7560-7567

Schloss PD, Handelsman J (2005) Introducing DOTUR, a computer program for defining operational taxonomic units and estimating species richness. Appl Environ Microbiol 71:1501-1506

Shen C, Xiong J, Zhang H, Feng Y, Lin X, Li X, Liang W, Chu H (2013) Soil pH drives the spatial distribution of bacterial communities along elevation on Changbai Mountain. Soil Biol Biochem 57:204-211

Singh D, Lee-Cruz L, Kim WS, Kerfahi D, Chun JH, Adams JM (2014) Strong elevational trends in soil bacterial community composition on Mt. Halla, South Korea. Soil Biol Biochem 68:140-149

Singh D, Takahashi K, Kim M, Chun J, Adams JM (2012) A hump-backed trend in bacterial diversity with elevation on Mount Fuji, Japan. Microb Ecol 63:429-437

Wang Q, Garrity GM, Tiedje JM, Cole JR (2007) Naïve Bayesian Classifier for rapid assignment of rRNA sequences into the new bacterial taxonomy. Appl Environ Microbiol 73:5261-5267

Ward NL, Challacombe JF, Janssen PH, Henrissat B, Coutinho PM, Wu M, Xie G, Haft DH, Sait M, Badger J, Barabote RD, Bradley B, Brettin TS, Brinkac LM, Bruce D, Creasy T, Daugherty SC, Davidsen TM, DeBoy RT, Detter JC, Dodson RJ, Durkin AS, Ganapathy A, Gwinn-Giglio M, Han CS, Khouri H, Kiss H, Kothari SP, Madupu R, Nelson KE, Nelson WC, Paulsen I, Penn K, Ren Q, Rosovitz MJ, Selengut JD, Shrivastava S, Sullivan SA, Tapia R, Thompson LS, Watkins KL, Yang Q, Yu C, Zafar N, Zhou L, Kuske CR (2009) Three genomes from the phylum Acidobacteria provide insight into the lifestyles of these microorganisms in soils. Appl Environ Microbiol 75:2046-2056

Yarwood SA, Myrold DD, Högberg MN (2009) Termination of belowground C allocation by trees alters soil fungal and bacterial communities in a boreal forest. FEMS Microbiol Ecol 70:151-162

Yergeau E, Bezemer TM, Hedlund K, Mortimer SR, Kowalchuk GA, Van Der Putten WH (2010) Influences of space, soil, nematodes and plants on microbial community composition of chalk grassland soils. Environ Microbiol 12:2096-2106

Zhang L, Xu Z (2008) Assessing bacterial diversity in soil. J Soils Sediments 8:379-388

Zhang LM, Wang M, Prosser Jl, Zheng YM, He JZ (2009) Altitude ammoniaoxidizing bacteria and archaea in soils of Mount Everest. FEMS Microbiol Ecol 70:208-217

\section{Submit your manuscript to a SpringerOpen ${ }^{\odot}$ journal and benefit from:}

- Convenient online submission

- Rigorous peer review

- Immediate publication on acceptance

- Open access: articles freely available online

- High visibility within the field

- Retaining the copyright to your article

Submit your next manuscript at $>$ springeropen.com 